\title{
Writing against oneself: Chabani Manganyi as a Black autobiographical subject
}

As a postcolonial society, it could be said - without fear of exaggeration - that South Africa has by far produced the most "life writing" or "autobiographical" writing. Of course, this didn't begin with the end of apartheid but it is also complicated to write or think about this genre as anything but part of our postcolonial condition. The range of "life writing" is wide - including for example, the madam / maid autobiographies beginning with Elsa Joubert Die swerfjare van Poppie Nongena (1978; translated and published in English in 1980 as The long journey of Poppie Nongena) via Shula Marks' Not either an experimental doll (1987) to Marlene van Niekerk's Agaat (2010). This range covers both fiction and non-fiction since one of South Africa's "reluctant" autobiographical subjects, the novelist J M Coetzee has written at least two "autre-biographical" accounts titled Boyhood: Scenes from a provincial life (1997) and Youth (2002). This distinction between the "fictional", the "factional" and the "real" is also important to Manganyi's memoir since he begins with a rumination on the dangers and pleasures of memory - or, what he terms, citing the work of Charles Fernyhough, "the 'first-person nature of memory"” (2016: xv). Importantly, the spectrum that ranges from the "transparent" subject to the "reluctant" subject is also useful in understanding why someone such as Winnie Mandela has for example refused to surrender her story to the auto/biography so that writers are forced to write in her "absence" even though she is very much alive. Thus, texts such as Njabulo Ndebele's The cry of Winnie Mandela: A novel (2003) open these many avenues for thinking about why auto/biography is an appealing genre for thinking about who a postcolonial subject might be.

\section{Hlonipha Mokoena}

W i S E R (Wits Institute for Social and Economic Research) University of the Witwatersrand Johannesburg hlonipha.mokoena@wits.ac.za 
This very brief survey of life writing in South Africa is also a map of Manganyi's own emergence as a biographer. Although there are many other parallelisms in the memoir, this one is the most fruitful since Manganyi trained as a psychologist; a fact he foregrounds in his title by connecting his academic career with both the apartheid state and the fact of being black. However, Manganyi is not a conventional "black subject"; the purpose of the memoir, he tells the reader, is to narrate the "story of how I became a man, a citizen and a scholar" (2016: xi). Thus, although the book contains many examples of discrimination and racism that Manganyi experienced in his career development, he doesn't seem to want to dwell on this. He is in the words of the foreword by Grahame Hayes, much more focussed on the objective set out in his earliest writings, namely, "to liberate black subjectivity" (2016: ix). It is therefore this life-long engagement with black subjectivity that makes Manganyi's memoir relevant (in its exposition on the history of the professional training of black psychologists) and timely (in its pioneering justification of black subjecthood as auto/biographical rather than just as sociological). In these two important ways, Manganyi's memoir should be compulsory reading for psychologists in training as well as those who aspire to contribute to the extant and diverse storehouse of life writing that already exists in South Africa.

Although it may seem to be a revealing and honest self-analysis, Manganyi's memoir contains at least one obvious gaping hole and that is his unwillingness to think of racism as a hindrance. As noted in my introduction, Manganyi seems to be content with the role of liberating black subjectivity rather than of challenging the root cause of racism. This may seem peculiar for a psychologist who entered his profession at a time when apartheid's "separate development" and its attendant creation of ersatz independent states called bantustans, went into full force. Even his school career was circumscribed by the victory of the National Party. Although he attended a missionary school; he was, as he writes, one of the last cohort of the school's matriculants to escape the grasp of Bantu education. He is admitted to study for a BA degree at a bush university (the recently established University College of the North or Turfloop as it became popularly known). Later in his career, his life circles back to homeland politics when he takes up a position at the institution that later became the "independent University of the Transkei'" (2016: 50). All of this should have added up into a scathing indictment of apartheid or at least an indignation at the raw deal that he was served. But, not Manganyi. Instead, he reads many of the conditions created by apartheid in his work and "thinking" spaces as the consequences of interpersonal relationships gone awry rather than as direct consequences of being a black man living in a racist society. Thus, even his experiences of being a black graduate struggling to find a job, are read as the failure of would be employers to appreciate the value of having well-trained black professionals (2016: cf 21-22). Even when he writes about his work for the furniture company Ellerines, from which he was told to resign because "employers 
such as the Ellerines brothers had no room for independent-minded black people like me" (2016: 26); Manganyi expresses no bitterness. It is ironic that it is when he is in the United States and he is passed up for a job and an African-American woman is hired instead that he comes to terms with "the feeling of victimization I nursed as a black South African" (2016: 49). It is also while on a fellowship in the United States that he begins writing Mashangu's reverie (1977), a semi-autobiographical work which as he states it, coincides with his encounter with America and "a gross kind of suffering which was gradually transformed into angry anguish" (2016: 46-47). Thus, it is both the liberation of being away from home and the contact with the close workings of American affirmative action that trigger Manganyi's reckoning with his own anger at the manner in which his country had treated him as a black person. Thus, it seems to be distance and remove that impels him to think through the effects of segregation and racism on his life and psyche. Yet, even here, Manganyi is still circumspect. When he re-reads his semi-autobiographical memoir, he is still much more focussed on the place of the book in his development as an auto/biographer. He is not therefore invested in the idea that Mashangu's reverie is about him; rather that it was about the process of become a life writer. The persona of Mashangu also becomes an everyman, "I understood that its hero, Mashangu, represents much more than elements of my life story. The memoir reflects the psychological and emotional struggles of the oppressed as seen and represented in Mashangu's experience" (2016: 67).

A similar tone of struggle pervades Manganyi's assessment of his three biographies of South African artists. In the latter cases, it is the alienation of exile that becomes the lynchpin around which as a biographer he hangs the life stories of Es'kia Mphahlele (the novelist), Gerard Sekoto (the fine artist) and Dumile Feni (the fine artist and sculptor). Each of the protagonists is a stand in for a larger canvas of the South African condition of exile: for Mphahlele, it is not just the fact that he is "self-exiled" (2016: 57) but that his peripatetic form of exile (and his return) corresponds with Manganyi's own sense of the tool of the biographical interview as a "choreographed witnessing of a life in progress" (2016: 73). For Sekoto, the main theme for contemplation for Manganyi seems to be his accidental role in the "history of the repatriation of Gerard Sekoto's artistic reputation in his country of birth" (2016: 85). This term reappears in an interview with Sean O'Toole in which Manganyi is cited as having spoken of Sekoto's biography as a "repatriation of legacy" (2016: 93). The last biographical subject, Dumile Feni, presents Manganyi with yet another re-evaluation of his role as biographer. In his case, it is the very absence of the material for a conventional biography that compels Manganyi to regard him from the vantage point of that "special pathos" of dying in a foreign place (2016: 96) while also following the "tracks" of Feni's life, especially his own musings "on the 'pain of others' - people he once described as individuals with 'vandalised minds' - as well as the agony of those among our people who were 
murdered by the agents of the apartheid regime simply for daring to be freedom fighters" (2016: 98, 99). When taken together these biographical subjects are what confirmed Manganyi's ascendance as a "psychologist-biographer" (2016: 80). However, what is also important is that unlike the biographers that Manganyi was reading and to some extent emulating - from Jean-Paul Sartre to Janet Malcolm (Sylvia Plath's biographer) - his work was beset by the interruption of having to venture into the the unknown terrain of forensic psychology. It is here that one sees how Manganyi comes to his own as an "autre-biographer" (to borrow Coetzee's term) since it is when he has to write and think in defense of the accused and the possibly condemned that his own life and work as a psychologist acquires an acute and agonising urgency. Thus, in between his biography of Mphahlele and that of Sekoto, he finds himself an "expert witness" (2016: 95) and a participant in the "soup" of "South African political violence and apartheid justice" (2016: 101). Here the life story, becomes for Manganyi, also a life and death story.

In an interview with Thengani Ngwenya for the volume Selves in question: Interviews on southern African auto/biography (2006), Manganyi explains that the "truth of the subject" is not just that when the biographer writes about their subject, they are also writing about themselves; it is also that, "you have to, as Jean-Paul Sartre once put it, overcome your own prejudices, you must write against yourself" (2006: 161). When read from this position, it could be argued that even in his memoir, Manganyi is writing against himself. His constant restraint and his reigning in of what could become emotional outbursts reveal a writer who is aware of the artifice involved in constructing himself as a biographical subject. Yet, it is not a duplicitous artifice since Manganyi is also at pains to distance himself from narratives of victimhood. It is this that makes Manganyi's autobiography a career triumph. He is able to look at his own life and career in retrospective - respecting all the failings and shortcomings of his memory - while at the same time, expressing the meaning of Mashangu's words: "The black man must stop feeling victimized. He must stand up straight, tall and clearly"” (2016: 67). So it is then that Chabani Manganyi presents himself as the black autobiographical subject who refuses to glorify the positionality of victimhood; he chooses instead the complexity of the author-subject whose own life is a work in progress.

\section{References}

Coetzee, J M (1997) Boyhood: Scenes from provincial life. New York: Penguin Books.

Coetzee, J M (2002) Youth. New York: Viking.

Coullie, J L (2006) Selves in question: Interviews on Southern African auto/

Biography. Honolulu: University of Hawai'i Press. 
Joubert, E (1978) Die swerfjare van Poppie Nongena. Kaapstad: Tafelberg.

Joubert, E (1980) The long journey of Poppie Nongena. Johannesburg: Jonathan Ball. Manganyi, N C (1977) Mashangu's reverie and other essays. Johannesburg: Ravan press.

Manganyi, N C (2016) Apartheid and the making of a Black psychologist. Johannesburg: Wits University Press.

Marks, S (ed) (1987) Not either an experimental doll: the separate worlds of three South African women: correspondence of Lily Moya, Mabel Palmer, and Sibusisiwe Makhanya. Bloomington: Indiana University Press.

Ndebele, N S (2003) The cry of Winnie Mandela: A novel. Claremont: David Philip Publishers.

Van Niekerk, M (2010) Agaat. Johannesburg: Jonathan Ball Publishers. 